\title{
IMPACT OF DIFFERENT ORGANIC FOOD SOURCES ON THE GROWTH AND REPRODUCTIVE PERFORMANCE OF COMPOSTING EARTHWORMS EISENIA FETIDA AND PERIONYX SANSIBARICUS
}

\author{
SURESH KUMAR ${ }^{1 *}$ and G. TRIPATHI \\ 'Department of Zoology, Govt. College, Sirohi (Rajasthan) \\ ${ }^{2}$ Department of Zoology, J.N.V. University, Jodhpur (Rajasthan)
}

\begin{abstract}
The present assessment has been designed to study the effect of different organic waste material viz.; leaf litter and kitchen waste plus goat dung $(1+1+2)$, fennel straw plus cow dung $(1+1)$, groundnut straw plus cow dung $(1+1)$ and castor straw plus cow dung $(1+1)$ used as bedding mixture on growth and different life cycle stages of composting epigeic earthworm species (Oligochaeta) : Eisenia fetida and Perionyx sansibaricus under laboratory condition for 90 days. Evaluation of their life stages in a particular bedding mixture may be beneficial for large-scale earthworm production. Rapid maturity rate $29.34 \pm 1.45$ day and incubation period of cocoon $10.33 \pm 0.34$ day of Eisenia fetida was observed in groundnut straw plus cow dung bedding, while earlier maturity rate $41.00 \pm 3.05$ day and incubation period of cocoon $13.00 \pm 0.55$ day of Perionyx sansibaricus recorded in leaf litter and kitchen waste plus goat dung containing culture. High cocoon production rate was noted in Eisenia fetida $(1.88 \pm 0.02$ worm/week) in the groundnut straw plus cow dung bedding and in Perionyx sansibaricus $(1.21 \pm 0.25 \mathrm{worm} / \mathrm{week})$ in leaf litter and kitchen waste plus goat dung bedding. Maximum number of cocoon hatchling of Eisenia fetida, $3.69 \pm 0.06$ no/cocoon was observed in culture containing groundnut straw plus cow dung bedding and in Perionyx sansibaricus highest hatchling success rate was recorded $2.28 \pm 0.08 \mathrm{no} /$ cocoon in leaf litter and kitchen waste plus goat dung bedding. The biomass growth of Eisenia fetida and Perionyx sansibaricus also observed and it was higher in groundnut straw plus cow dung and leaf litter and kitchen waste plus goat dung bedding material respectively. Both the species performed poorly in bedding containing castor straw plus cow dung organic material. The present result concludes that the growth and reproductive strategy of worms shows suitability in a particular organic waste material.
\end{abstract}

Key words : Epigeic, Life cycle, Culture, Hatchling, Bedding material.

\section{INTRODUCTION}

Vermicomposting is an eco-biotechnology in which earthworms helps to transform complex organic material into stabilized humus-like product vermicompost. It refers to the use of earthworms on a large scale to produce eco-friendly compost from organic wastes and involves detailed planning to provide the optimum conditions for the growth and reproduction of earthworms (Hartenstein,1981). All aspects of the earthworm biology such as growth and reproductive potential must be known in order to utilize the earthworms successfully in vermicomposting (Senapathi and Das,1984). Suitable species of earthworms, the quality and type of raw materials, temperature, moisture, aeration and number of earthworms seem to influence the vermicomposting process (Jambhekar,1992). Biology of earthworm species suitable for vermicomposting has been described by Dominguez and Edwards (2010). In any case, the high biomass, high production coupled with high instantaneous growth rate and higher turnover values are some of the positive attributes of the species for vermicomposting (Sinha et al.,2002). The reproduction, biomass growth, vermicompost yield and quality have been suggested to be stimulated by quality and intake of feed by earthworms (Bohlen,2002). Vermicomposting potential of E.fetida and P.excavatus by using a variety of waste materials such as cattle dung (Chaudhuri and Bhattacharjee,2002), household waste, sewage sludge, industrial waste, etc. (Edwards,2004 and Suthar,2006) is being investigated. Bhat et al. (2018) re- ported that earthworms were used as a organic managers and biofertilizer producer.

The end product, i.e. vermicompost is considered as an excellent product, since it is homogenous, has desirable aesthetics, has reduced levels of contaminants and tends to hold more nutrients over a longer period without impacting the environment. Rapid urbanization resulted in an ever-increasing accumulation of urban solid waste. In India, domestic waste is mostly of organic nature and contributes $70-80 \%$ to the total solid urban waste. However, it can be used as a potential resource for transformation from expensive disposal problem to stabilized vermicompost production for sustainable land restoration practices. The growth patterns E.fetida in number of different organic waste resources have been investigated by various authors in laboratory culture (Edwards, 1998; Kaplan et al.,1980; Kaushik \& Garg 2003 and Garg \& Kaushik,2005). The influence of different food sources on growth and reproduction performance of P.sansibaricus were studied by Suthar (2007). Gunadi et al. (2002) and Gunadi \& Edwards (2003) have studied growth, reproduction, and mortality of E.fetida for over a year in solid manure, pig manure, and supermarket waste solids.

P.sansibaricus are considered as endemic species while E.fetida are to be considered as exotic earthworm species. But, little is known about the composting use of P.sansibaricus. Therefore, to establish the use of this species for vermicomposting operations, proper research work is still 
required. Since both species of earthworm have distinct morphological characteristics and also possibly waste degradation patterns their reproductive potential under different organic ambience warrants appropriate experimental confirmation. Besides, comparative studies on composting efficiencies on these species duly need richer literature. Understanding the growth and reproductive efficiency of vermicomposting worms in various substrates is highly essential for effective utilization of earthworms in sustainable waste management system (Appelhof et al.,1996 and Jesikha \& Lekeshmanaswamy,2013). Ali and Kashem (2018) has determined the cocoon production rate, hatching success, number of hatchling and growth of Eisenia fetida and Eudrilus eugeniae in the media containing cowdung.

The comparison of the composting efficiency can be performed by using a common substrate for both species such as fennel straw and groundnut straw. Since every species has specific patterns of utilization of nutrient provided by the bedding material, this protocol is also justifying as they may have not been previously tested as vermicomposting substrates. In this study, efforts have been made to compare the composting potential of E.fetida and P.sansibaricus by using a common culture material an agro waste that had not been explored extensively in previous studies.

\section{MATERIAL AND METHODS}

Preparation of bedding and earthworm culture : Four different types of bedding materials mix substrate were used for experimentation. These bedding materials not only served as bedding but also as a food source for earthworms. The substrates used were as follows : (a) Leaf litter and kitchen waste plus goat dung, (b) groundnut straw plus cow dung, (c) fennel straw plus cow dung and (d) castor straw plus cow dung. All these bedding materials were collected from household waste (kitchen waste), goashala (dung), university campus, Jodhpur (leaf litter) and agricultural land area (agricultural waste) of Sirohi. Life cycle experiments were carried out under laboratory condition with average moisture levels of $60-80 \%$. During the process, moisture was maintained by watering the vermibeds regularly. The temperature of vermibeds was $27 \pm$ $3^{\circ} \mathrm{C}$ and was maintained by using jute cloths. In this experiment two earthworm species (Eisenia fetida and Perionyx sansibaricus) were designated in triplicate sets of vermibeds (each $3 \mathrm{~kg}$ ) prepared in a ratio of 1:1 in plastic containers $(30$ $\mathrm{cm}$ diameter $\mathrm{x} 25 \mathrm{~cm}$ height) and moistened to stabilize within 48 hours. Employed earthworms E.fetida were obtained from vermicompost unit of Kanhaiya goashala, Pal Balaji Road, Jodhpur, and other species P.sansibaricus was collected from field (Sirohi). In the experimental sets 25 worms of each species were inoculated separately. One set of control bedding material (without earthworm) was run simultaneously. The culturing plastic containers were perforated at 2-3 places to facilitate leaching of excess water. The vermiculture experiments were conducted for 90 days and maturation, cocoon production, incubation of cocoon and hatchling count were observed as the experimental layout described below.

Biomass, maturation period and cocoon production rate : Five hatchlings of earthworm species in good health condition were taken from the experimental containers for reproductive potential determination. The hatchlings were washed with distilled water to remove any dirt stick on, dried briefly on paper towel, weighed on electronic balance and finally introduced in each respective experimental container. Three replicates were established to monitor the growth and maturation progress daily, the biomass was measured in cluster of earthworm in each container and mature phases was observed. The substrate in treatment container was examined daily in order to determine the onset of cocoon production. Once the cocoons appeared, they were separated by hand sorting, washed lightly in distilled water and counted to determine total number of cocoon rate (no of cocoon/worm/week). No additional feed was added at the time of measurements. On the basis of the obtained data the gain in biomass of the worms (g/ worms) were calculated.

Incubation period of cocoon and number of hatchlings : To determine the incubation period and number of hatching per cocoons, fifteen freshly laid cocoons from treatment were taken from the above containers and placed in containers which contained the same material in which their parents were reared. Three replicates were prepared. The bedding were observed daily for the emergence of hatchlings in order to determine the incubation period. As soon as the appearance of hatchling started, they were removed daily using a fine painting brush and counted by hand sorting in order to determine the total number of hatchlings that emerged from a cocoon. The number of un-hatched cocoons was also counted in order to find out the hatching success of cocoons.

\section{RESULTS AND DISCUSSION}

A. Life cycle of Eisenia fetida : Incubation period of E.fetida varied significantly $(\mathrm{P}<0.05)$ with respect to changes in bed-

Table. 1 Effect of different bedding materials on the life of cycle of E.fetida. Each datum is the mean \pm SEM of three replicates.

\begin{tabular}{|c|c|c|c|c|c|}
\hline Bedding materials & $\begin{array}{l}\text { No. of cocoon } \\
\text { worm/week }\end{array}$ & $\begin{array}{l}\text { Incubation period } \\
\text { of cocoon (day) }\end{array}$ & $\begin{array}{l}\text { No. of hatchling } \\
\text { (No./cocoon) }\end{array}$ & $\begin{array}{c}\text { Maturation period } \\
\text { (day) }\end{array}$ & $\begin{array}{c}\text { Biomass } \\
\text { (g/worms) }\end{array}$ \\
\hline Leaf litter and kitchen waste plus goat dung & $1.60 \pm 0.047$ & $16.67 \pm 1.202$ & $2.12 \pm 0.065$ & $37.00 \pm 1.528$ & $0.49 \pm 0.012$ \\
\hline Castor straw plus cow dung & $1.34 \pm 0.031$ & $18.67 \pm 0.667$ & $1.71 \pm 0.085$ & $50.67 \pm 1.763$ & $0.42 \pm 0.021$ \\
\hline Fennel straw plus cow dung & $1.72 \pm 0.040$ & $14.33 \pm 1.202$ & $2.90 \pm 0.065$ & $34.67 \pm 1.202$ & $0.53 \pm 0.011$ \\
\hline Ground nut straw plus cow dung & $1.88 \pm 0.020$ & $10.33 \pm 0.334$ & $3.69 \pm 0.066$ & $29.34 \pm 1.452$ & $0.61 \pm 0.013$ \\
\hline F-value & 43.37 & 14.89 & 151.47 & 36.68 & 25.11 \\
\hline P-value & $<0.001$ & $<0.05$ & $<0.001$ & $<0.001$ & $<0.001$ \\
\hline
\end{tabular}




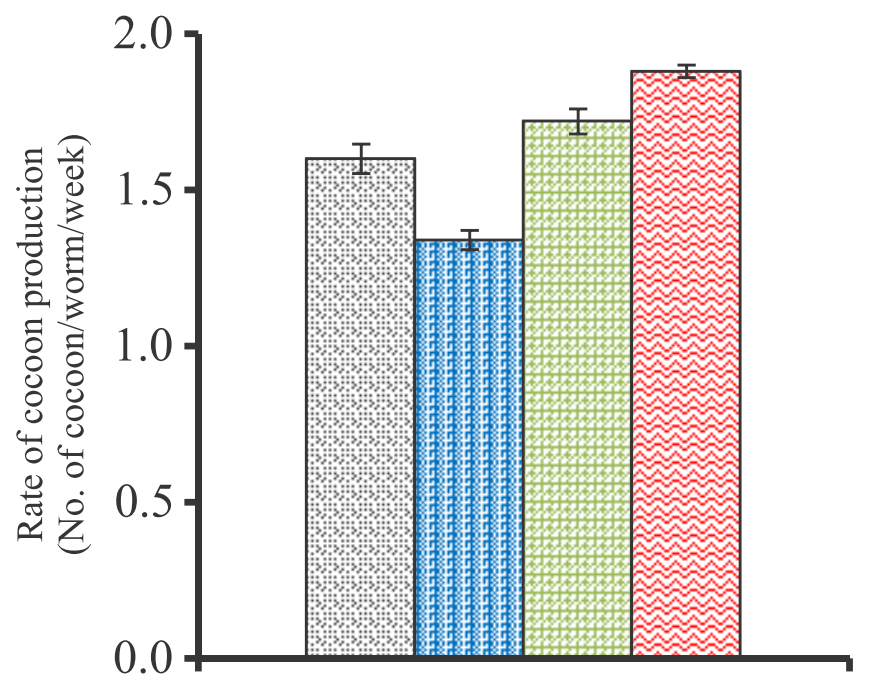

ding materials (Table.1). Smallest incubation duration was observed in groundnut straw plus cow dung bedding, and longest incubation period was observed in caster straw plus cow dung. Whereas leaf litter and kitchen waste plus goat dung and fennel straw plus cow dung bedding showed moderate values of incubation period. Beside this, number of hatchlings per cocoon, number of cocoon production per worm, maturation period of worm and biomass of sexually matured worm showed significant $(\mathrm{P}<0.001)$ variations in their values with respect to changes in bedding materials (Table.1 \& Fig.1).

\author{
圈 Leaf litter and kitchen waste plus Goatdung \\ 国 Castor straw plus Cowdung \\ Gennel straw plus Cowdung \\ ⿴囗大 Ground nut straw plus Cowdung
}
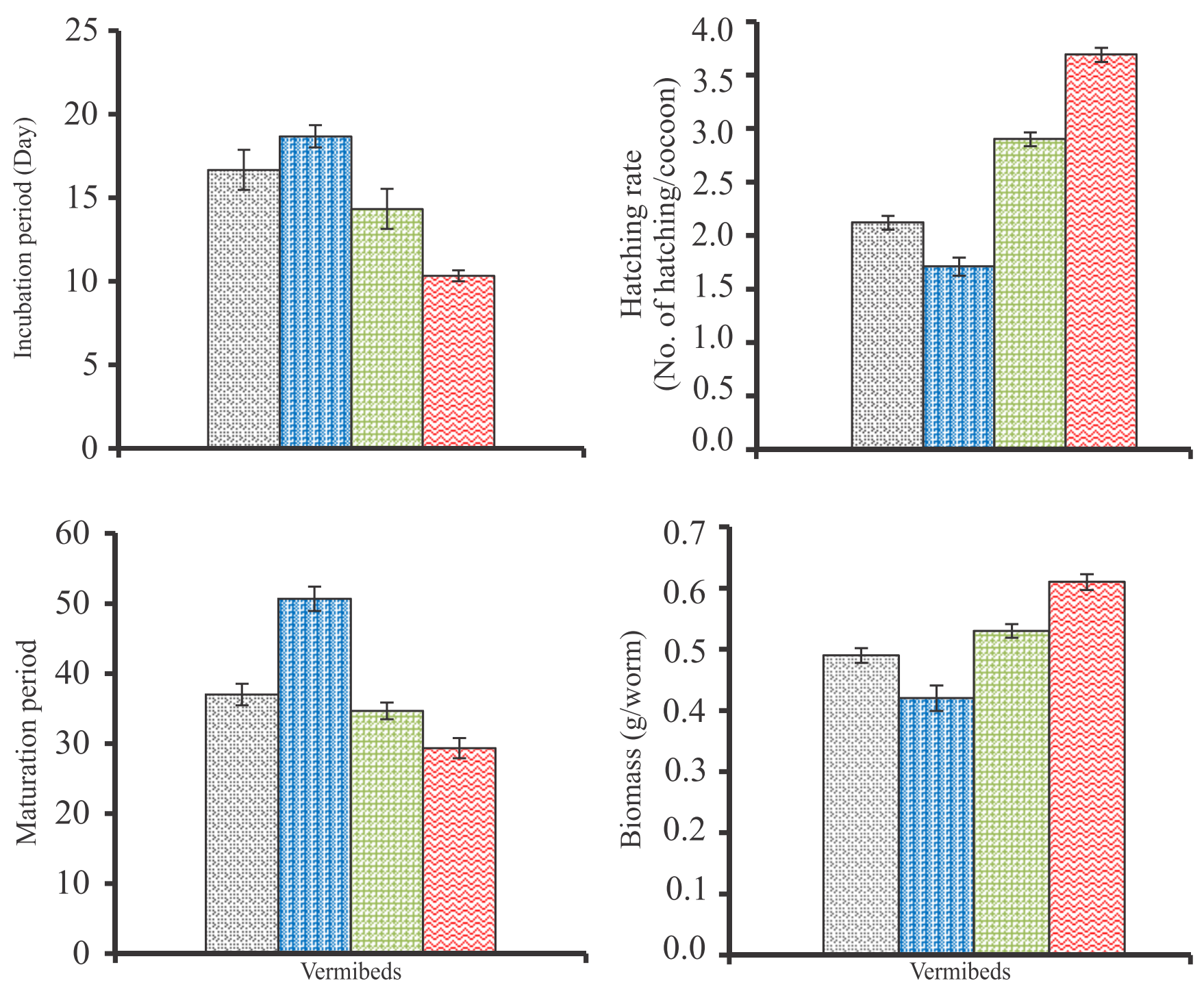

Fig. 1 Effect of different bedding materials on production of cocoon, incubation period, number of hatchlings per cocoon, maturation period and biomass of Eisenia fetida. 
B. Life cycle of Perionyx sansibaricus : The value of incubation period, number of hatchling per cocoon, number of cocoon production per worm, maturation period of worm and biomass of sexually matured P.sansibaricus significantly $(\mathrm{P}<0.001)$ changed in relation to different bedding materials (Table.2). Maximum value of cocoon production per worm, hatchling per cocoon and wet biomass of earthworm were reported in leaf litter and kitchen waste plus goat dung bedding, while minimum was found in caster straw plus cow dung. The groundnut straw plus cow dung and fennel straw plus cow dung bedding showed moderate values of mentioned parameters. Therefore, lowest incubation and maturation period were recorded in leaf litter and kitchen waste plus goat dung bedding, while highest was found in caster straw plus cow dung. On the other hand, groundnut straw plus cow dung and fennel straw plus cow dung bedding exhibited moderate values (Table.2 \& Fig.2).

Life cycle stages : Reproductive potential of E.fetida and P.sansibaricus were studied in different bedding substrates viz., leaf litter and kitchen waste plus goat dung, castor straw plus cow dung, fennel straw plus cow dung and groundnut straw plus cow dung (Tables.1\&2). The values of cocoon/ worm/week, incubation period, hatchling/cocoon, maturation period and biomass of E.fetida and P.sansibaricus varied significantly $(\mathrm{P}<0.001-0.05)$ with respect to different bedding materials.

The reproductive rate, number of cocoon production, number of hatchling per cocoon and biomass values of E.fetida and P.sansibaricus were significantly higher in groundnut straw plus cow dung and leaf litter and kitchen waste plus goat dung bedding respectively, while these were lowest in caster straw plus cow dung bedding for both (Tables. $1 \& 2$ and Figs. $1 \& 2)$. It may be due to rapid decomposing nature, easy digestibility with good sustenance values of bedding substrates which facilitate the more rapid growth and more cocoon production. Neuhauser et al. (1980) reported that the rate of weight gain by E.foetida is dependent on population density and the type of food. During composting period microbial growth play an important role in earthworm nutrition and fast growth as well as cocoon production of earthworm species (Fayolle et al.,1997).

In laboratory condition physio-chemical properties had a remarkable growth, metabolism and cocoon production in E.fetida than P.sansibaricus added bedding substrate. Loh et al. (2005) also described that biomass gain and cocoon production by E.fetida was more in cattle waste than goat waste.
Time of maturation of cocoons and cocoon production vary with species, population density, age structure and external factors specially soil temperature, moisture and energy content of the available food (Lee, 1985; Julka, 1988 and Edwards \& Bohlen, 1996).

In the present study shortest incubation and maturation period, maximum hatchling/cocoon and biomass of E. fetida were observed in ground straw plus cow dung bedding. Whereas, P.sansibaricus showed shortest incubation and maturation period, maximum hatchling/cocoon and biomass in leaf litter and kitchen waste plus goat dung bedding material. However, caster straw plus cow dung bedding substrate exhibited poor performance of cocoon production per week, incubation period, hatchling/cocoon, maturation period and biomass of both species. The palatability and nutritive superiority of feeding substrate may play an important role in reproductive potential of earthworms. When earthworms were cultured on different fed substrates they showed variation in their growth (Kale \& Bano,1992; Viljoen \& Reinecke,1994 and Dominguez et al.,2001). Ndegwa et al. (2000), Tripathi \& Bhardwaj (2004), Gajalakshmi et al. (2005), Garg et al. (2005) and Parthasarathi (2007) also reported that the different substrates directly influence the growth, survival and reproductive potential of earthworms.

Incubation period of cocoon of both studied worms varies in between 10.33-22.33 day; it is supported by Reinecke $e t$ al. (1992) who reported that a mean incubation period is 15 17.8 days for cocoon of tropical earthworm. Bisht et al. (2007) observed that cocoon development time of a species also varied with the media for incubation. Number of hatchlings per cocoon is recorded as 1.71-3.69 for E.fetida in different bedding substrates. Edwards (1998) reported mean number of hatchlings per cocoon as 3.3 for E.fetida. Chaudhury and Bhattacharjee (2011) stated the shape, size, development time and hatching success of cocoons differed greatly among earthworm species in different wastes.

The reports of Bohlen (2002) also supported the present findings that the nutritive superiority of feed substrate stimulates the time of sexual maturity in earthworms. More or less similar results have been described by other workers showing different life phases and sexual maturity of E.fetida in different beddings (Neuhauser et al.,1979; Hartenstein \& Hartenstein,1881; Edwards et al.,1985; Venter \& Reinecke, 1988; Reinecke et al.,1992; Garg et al.,2005 and Khomami et al.,2016). Development of E.fetida was better in cow dung bedding substrate, whereas P.sansibaricus showed greater re-

Table. 2 Effect of different bedding materials on the life of cycle of P.sansibaricus. Each datum is the mean \pm SEM of three replicates.

\begin{tabular}{lccccc}
\hline Bedding materials & $\begin{array}{c}\text { No. of cocoon } \\
\text { worm/week }\end{array}$ & $\begin{array}{c}\text { Incubation period } \\
\text { of cocoon (day) }\end{array}$ & $\begin{array}{c}\text { No. of hatchling } \\
\text { (No./cocoon) }\end{array}$ & $\begin{array}{c}\text { Maturation period } \\
\text { (day) }\end{array}$ & $\begin{array}{c}\text { Biomass } \\
\text { (g/worms) }\end{array}$ \\
\hline Leaf litter and kitchen waste plus goat dung & $1.21 \pm 0.025$ & $13.00 \pm 0.0557$ & $2.28 \pm 0.084$ & $41.00 \pm 3.055$ & $0.45 \pm 0.006$ \\
Castor straw plus cow dung & $0.70 \pm 0.018$ & $22.33 \pm 0.667$ & $1.55 \pm 0.030$ & $73.67 \pm 1.856$ & $0.33 \pm 0.012$ \\
Fennel straw plus cow dung & $0.91 \pm 0.040$ & $16.33 \pm 0.082$ & $1.87 \pm 0.052$ & $58.67 \pm 1.453$ & $0.37 \pm 0.006$ \\
Ground nut straw plus cow dung & $1.09 \pm 0.026$ & $14.00 \pm 0.557$ & $2.03 \pm 0.040$ & $50.67 \pm 1.202$ & $0.39 \pm 0.004$ \\
F-value & 61.85 & 37.07 & 30.81 & 46.74 & 38.01 \\
P-value & $<0.001$ & $<0.001$ & $<0.001$ & $<0.001$ & $<0.001$ \\
\hline
\end{tabular}




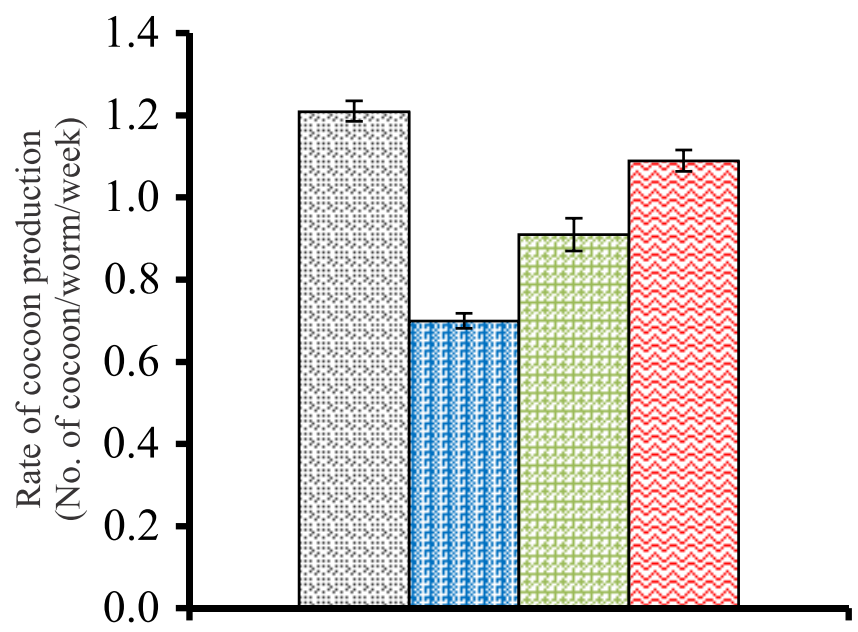

sults in leaf litter and kitchen waste plus goat dung. This may be supported by Garg et al. (2005) who concluded that the cocoon production and biomass of E.fetida was higher in cow dung bedding material than goat dung bedding manure. It may be attributed to feeding habit of exotic and local earthworm species. According to Singh et al. (2018) E.fetida was superior to other epigeic species and it tolerates wide range of temperature, moisture and pH. Ali \& Kashem (2018) and Bondhare \& Desai (2019) also reported that growth and reproduction of exotic species such as E.fetida is rapid in cow dung supplemented with farm wastes as compared to other local species.

国 Leaf litter and kitchen waste plus Goatdung 중 Castor straw plus Cowdung Q Fennel straw plus Cowdung 중 Ground nut straw plus Cowdung
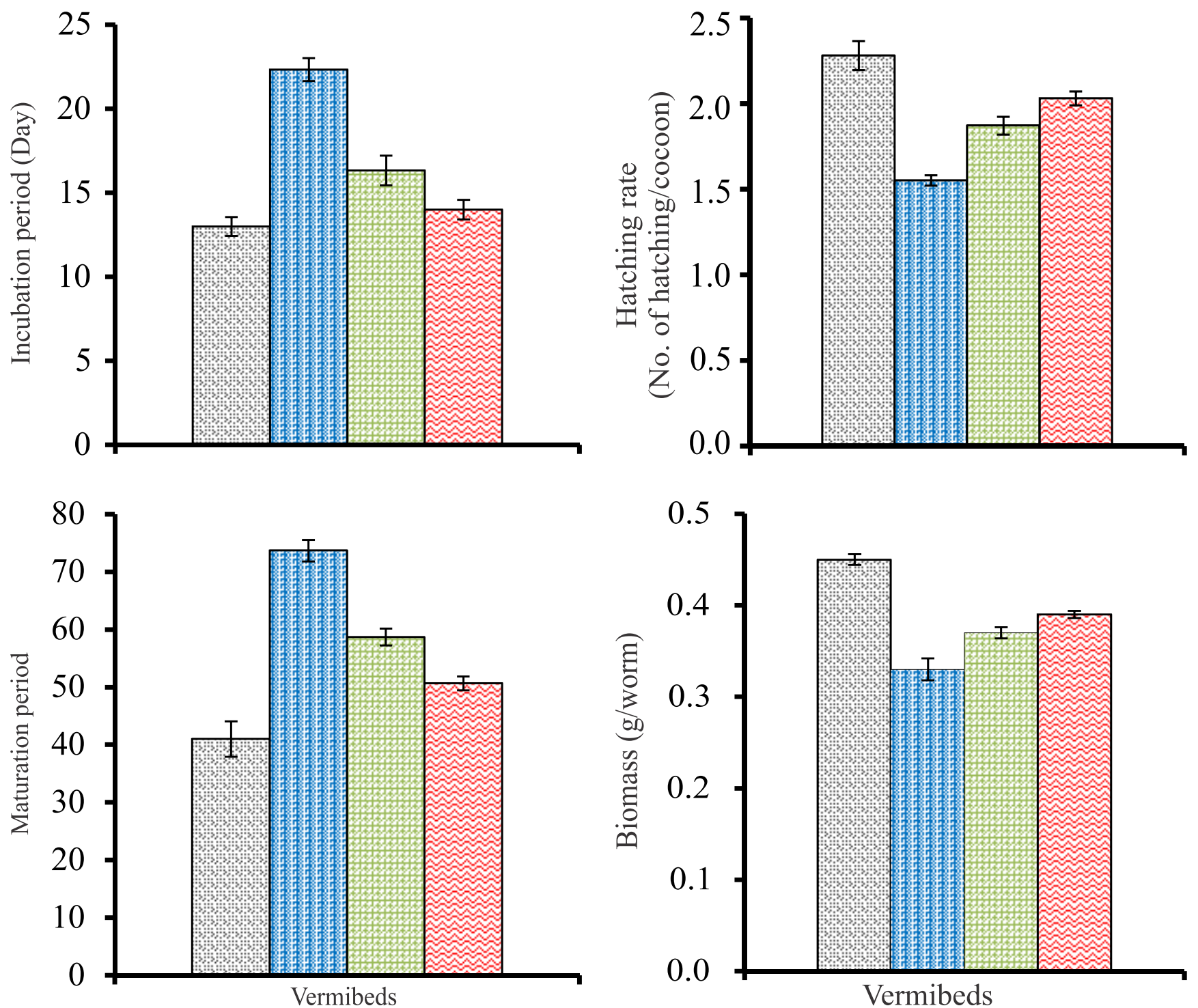

Fig. 2 Effect of different bedding materials on production of cocoon, incubation period, number of hatchlings per cocoon, maturation period and biomass of Perionyx sansibaricus. 
The variation in the rates of cocoon production could be due to differences in biochemical quality of the feeding substrates. According to Edwards et al. (1998) growth rate is a good indicator for comparing the different wastes suitable for growth of earthworms and also find out the time taken to attained sexual maturity. In contrast Garg et al. (2005) observed that in some bedding materials the weight gain by earthworms was more but cocoon production was lower than other feeds tested.

On the other hand, the more continuous and high rate of cocoon production as well as higher hatching success in E.fetida and P.sansibaricus indicated their possible usefulness in vermiculture for waste degradation as well as for soil reclamation depending upon the species (Bhattacharjee \& Chaudhuri,2002 and Chaudhuri \& Bhattacharjee,2011). Further a detailed and systemic study is required to divulge the facts about cocoon productivity, incubation period, number of hatchling/cocoon, maturation period and biomass dy- namics in different animals manure and agro-wastes in Rajasthan.

The reproduction potential of Eisenia fetida is higher than Perionyx sansibaricus. However, to know about their reproductive strategies in different wastes as a decomposer, it is important that the different life stages of the worms on bedding material be studied throughly. Eisenia fetida is most suitable earthworm species for composting than any other local species.

\section{ACKNOWLEDGMENTS}

The author would like to thanks to the University Grants Commission UGC-CRO, Bhopal for awarding UGCTRF under faculty development program. He also extends his gratitude to Department of Zoology, J.N.V. University, Jodhpur for providing lab facilities.

\section{REFERENCES}

Ali, S. and Kashem, M. A. (2018). Life cycle of composting earthworms Eisenia fetida and Eudrilius eugeniae under laboratory controlled condition. Bio. Med. J. Sci. Technl. Res., 10(5) : 8110-1813.

Appelhof, M.; Webster, K. and Buckerfield, J. (1996). Vermicomposting in Australia and New Zealand. Biocycle, 37 : 63-66.

Bhat, S. A.; Singh, J. and Pal Vig, A. (2018). Earthworms are used as a organic managers and biofertilizer producer. Waste and Biomass Valorization, 9 : 1073-1086

Bhattacharjee, G. and Chaudhuri, P. S. (2002). Cocoon production, morphology, hatching pattern and fecundity in seven tropical earthworm species : A laboratory based investigation. J. Biosci., $27: 283-294$.

Bisht, R.; Pandey, H.; Bharti, D.; Bisht, S. P. S. and Kaushal, B. R. (2007). Reproductive potential of the earthworm Metaphire posthuma (Oligochaeta) in different food substrates. Trop. Ecol., 48 : 107-114.

Bohlen, P. J. (2002). Earthworms, Encyclopedia of Soil Science. Marcel Dekker Inc. USA, pp. 370-373.

Bondhare, S. O. and Desai, R. B. (2019). Comparison of life cycle of earthworm Eisenia fetida and Lumbricus rubellus under laboratory controlled condition in Nanded district. J. Entl. Zool. Stud., 7(4) : 56-559.

Chaudhary, P. S. and Bhattacharjee, G. (2002). Capacity of various experimental diets to support biomass and reproduction of Perionyx excavates. Biores. Technol., $82: 147-150$

Chaudhuri, P. S. and Bhattacharjee, S. (2011). Reproductive biology of eight tropical earthworm species of rubber plantations in Tripura Trop. Ecol., $52: 49-60$.

Dominguez, J.; Edwards, C. A. and Ashby, J. (2001). The biology and population dynamics of Eudrilus eugeniae (Kinberg) (Oligochaeta) in cattle waste solids. Pedobiologia, $45: 341-353$

Dominguez, J. and Edwards, C. A. (2010). Biology and ecology of earthworms species used for vermicomposting, (C) 2011 by Taylor \& Francis Group, LLC Chapter, $3: 28-40$

Edwards, C. A.; Burrows, I.; Fletcher, K. E. and Jones, B. A. (1985). The use of earthworms for composting farm wastes, In : Composting agricultural and other wastes (ed. Gasser, J.K.R.). Elsevier, London and New York, pp. 229-241.

Edwards, C. A. and Bohlen, P. J. (1996). Biology and Ecology of Earthworms : $3^{\text {rd }}$ edn., Chapman and Hall, London, p. 426.

Edwards, C. A. (1998). The use of earthworms in the breakdown and management of organic wastes. In : Earthworm ecology (ed. Edwards C.A.). St. Lucie Press, Boca Raton, pp. 327-351

Edwards, C.A. (2004). Earthworm ecology, CRC publication.

Fayolle, L.; Mitchell, H.; Cluzeau, H. and Stawiec, D. (1997). Influence of temperature and food source on the life cycle of the earthworm Dendrobaena veneta (Oligochaeta). Soil Biol. Biochem., 29 : 747-750.

Gajalakshmi, S.; Ramaswami, E. V. and Abbasi, S. A. (2005). Compositing-vermin-composting of leaf litter ensuring from the trees of mango (Mangnifera indica). Bioresource Technol., 96: 1057-1061. 
Garg, V. K.; Chand, S.; Chhiller, A. and Yadav, A. (2005). Growth and reproduction of Eisenia fetida in various animal wastes during vermicompostiong. Appl. Ecol. Environ. Res., $3: 51-59$.

Garg, V. K. and Kaushik, P. (2005). Vermistabilization of textile mill sludge spiked with poultry droppings by an epigeic earthworm E.fetida, Bioresource Technol., 96 : 1063-1071.

Gunadi, B.; Blount, C. and Edwards, C. A. (2002). The growth and fecundity of E.foetida (savigny) in cattle solids pre-composted for different periods. Pedobiolagia, 46(1): 1523 .

Gunadi, B. and Edwards, C. A. (2003). The effect of multiple applications of different organic wastes on the growth, fecundity and survival of Eisenia foetida (Savigny) (Lumbricidae). Pedobiologia, 47(4) : 321-330.

Hartenstein, R. (1981). Use of Eisenia fetida in organic recycling based on laboratory experiments, In: Workshop on the role of earthworms in a stabilization of organic residues (ed. Appelhof, M.). Proc Beech Leaf Press, Michigan, 1 : 155-165.

Hartenstein, R. and Hartenstein F. (1981). Physio-chemical changes affected in activated sludge by earthworm Eisenia fetida. J. Environ. Qual., $10: 377-382$.

Jambhekar, H. A. (1992). Use of earthworm as a potential source to decompose organic wastes. In : Proc. Nat. Sem. Org. Fmg. MPKV, Pune, pp. 52-53.

Jesikha, M. and Lekeshmanaswamy, M. (2013). Effect of Pongamia leaf medium on growth of earthworm (E.eugeniae). Int. J. Sci. Res. Publ., 3(1) : 2250-3153.

Julka, J. M. (1988). The fauna of India and the adjacent countries. Megadrile : Oligochaeta (Earthworms), Haplotaxida : Lumbricina : Megascolecidae : Octochaetidea. Zoological Survey of India, Calcutta, p. xiv+400.

Kale, R. D. and Bano, K. (1992). Niche divergence - A limiting factor for recommendation of earthworms for biotechnology, In : Proc. Nat. Sem. Org. Fmg. Bangalore, pp. 42-44.

Kaplan, D. L.; Hartenstein, R.; Neuhauser, E. F. and Malecki, M. R. (1980). Physio-chemical requirements in the environment of the earthworm Eisenia foetida. Soil Biology and Biochemistry, $12: 347-352$.

Kaushik, P. and Garg, V. K. (2003). Vermicomposting of mixed solid textile mill sludge and cow dung with the epigeic earthworm E.fetida. Bioresour. Technol., $90: 311-316$

Khomami Mah, A.; Mammadov, G. M. and Fatemi Chokami, A. (2016). Sedaghathoor S. Growth and reproductive performance of E.foetida in cow manure, cow manure plus sugarcane bagasse and cow manure plus sawdust waste, Appl. Ecol. Environ. Res., 14: $237-247$.

Lee, K. E. (1985). Earthworms: Their ecology and relationship with soil and land use. Academic Press, Sydney, Australia, p. 411.

Loh, T. C.; Lee, Y. C.; Liang, J. B. and Tan D. (2005). Vermicomposting of cattle and goat manures by Eisenia foetida and their growth and reproduction preference. Bioresour. Technol., $96: 111-4$.

Ndegwa, P. M.; Thompson, S. A. and Das, K. C. (2000). Effects of stocking density and feeding rate on vermicomposting of bio solids. Biores Technol., $71: 5-12$.

Neuhauser, E. F.; Kaplan, D. L. and Hartenstein, R. (1979). Life history of the earthworm Eudrilus eugeniae (Kinberg). Rev. Ecol. Biol. Soil, $16: 524-534$.

Neuhauser, E. F.; Hartenstein, R. and Kaplan, D. L.(1980). Growth of the earthworm Eisenia foetida in relation to population density and food rationing. Oikos, $35: 93-98$.

Parthasarathi, K. (2007). Influence of moisture on the activity of Perionyx excavatus (Perrier) and microbial-nutrient dynamics of press mud vermicompost. Iran. J. Eniron. Health Sci. Eng., 4 : 47-156.

Reinecke, A. J.; Viljoen, S. A. and Saayman, R. J. (1992). The stability of Eudrilus eugeniae, Periony sansibaricus and Eisenia fettida (Oligochaeta) for vermicomposting in Southern Africa in terms of their temperature requirements. Soil. Biol. Biochem., 24 : $1295-1307$.

Senapati, B. K. and Dash, M. C. (1984). Functional role of earthworms in decomposer subsystem. Trop. Ecol., 25(2): 54-73.

Singh, J.; Singh, S.; Pal Vig, A. and Kaur, A. (2018). Environment influence of soil towards effective vermicomposting Earthworm. In : The ecological engineers of soil (ed. Sajal Ray). Intech Open.

Sinha, R. K.; Heart, S.; Agarwal, S.; Asadi, R. and Carretero, E. (2002). Vermiculture technology for environmental management : Study of the action of the earthworms Eisenia foetida, Eudrilus euginae and Perionyx excavatus on biodegradation of some community wastes in India and Australia. The Environmentalist, $22: 261-268$

Suthar, S. (2006). Potential utilization of guar gum industrial waste in vermicompost production. Biores. Technol., 97: $2474-2477$.

Suthar, S. (2007). Studied the influence of different food sources on growth and reproduction performance of composting epigeics : Eudrilus eugeniae, Perionyx excavatus and Perionyx sansibaricus. Applied Ecology and Environmental Research, 5(2): 79-92.

Tripathi, G. and Bhardwaj, P. (2004). Comparative studies on biomass production, life cycle and composting efficiency of Eisenia fetida (Savigny) and Lampito mauritii (Kinberg), Biores. Technol., $92: 275-283$.

Venter, J. M. and Reinecke, A. J. (1988). The life cycle of the compost worm Eisenia foetida (Oligochaeta). S. Afr. J. Zool., 23 : $161-165$.

Viljoen, S. A. and Reinecke, A. J. (1994). The life-cycle and reproduction of Eudrilus eugeniae under controlled environmental conditions. Mitt. Hamb. Zool. Mus. Inst., 89 : 149-157. 